Crop Breeding and Applied Biotechnology 13: 33-40, 2013

Brazilian Society of Plant Breeding. Printed in Brazil

\title{
ARTICLE
}

\section{Search for sources of resistance to Fusarium wilt (Fusarium oxysporum f. sp. vasinfectum) in okra germplasm}

\author{
Frederick Mendes Aguiarr ${ }^{1}$, Sami Jorge Michereff ${ }^{1}$, Leonardo Silva Boiteux ${ }^{2}$ and Ailton Reis ${ }^{2 *}$
}

Received 09 November 2011

Accepted 04 December 2012

\begin{abstract}
Fusarium oxysporum $f$. sp. vasinfectum (FOV) is one the most destructive okra (Abelmoschus esculentus) pathogens in Brazil. Fifty-four okra accessions were evaluated for resistance to FOV. Greenhouse screening was initially carried out with one FOV isolate ('Fus-194'). Inoculation (in all assays) was carried out with 21-day-old plantlets, using the root-dipping inoculation technique. Thirty-three accessions displaying differential responses in the first screening were re-evaluated in two additional assays, using two FOV isolates ('Fus-194' and 'Fus-201'). Twelve accessions were rated as highly to intermediately resistant to 'Fus-194' during the dry/moderate temperature season, whereas nine accessions were classified as highly to intermediately resistant to 'Fus-201'. In the assay carried out in the wet and warm season, $72 \%$ of the accessions were classified as having high and intermediate resistance to 'Fus-194', and 32\% were resistant to 'Fus-201'. The accessions 'Santa Cruz-47', 'BR-2399' and 'BR-1449' were the most promising resistance sources.
\end{abstract}

Key words: Abelmoschus esculentus, germplasm characterization, genetic resistance, breeding.

\section{INTRODUCTION}

Okra (Abelmoschus esculentus Moench, family Malvaceae) is an annual bush, with a vigorous semi-fibrous stalk, rapid vegetative cycle, and adaptation to high temperatures (Torres et al. 1998). The Center of origin of this species is most likely the warm climate areas of the continental Africa (Torres et al. 1998). Okra is relatively easy to be cultivated and it is considered an important cash crop for family-based farmers in many areas within developing countries (Filgueira 2003). Okra cultivation in tropical and subtropical regions is more intense due to the fact that it does not need high technological input to be successfully grown.

In Brazil, okra is a vegetable crop that is mainly cultivated by smallholders, and in some areas it can be the main source of family income. In addition, okra fruit is an important component of the regional cuisine, being a rich source of fibers, minerals, and vitamins (Oliveira et al. 2003). The climatic conditions in the country are favorable for the yearround okra cultivation, especially in the Northeast, CenterWest, and Southeast regions. The economic importance of this vegetable crop in many Brazilian regions leads to an intensive okra planting which has been done for decades. As a result, it has been observed a decrease in the size of the cultivated area, as well as in total fruit yield, due to poor management strategies and to diseases caused by bacteria, nematodes, virus, and fungi (Veras and Silva 2007).

The genus Fusarium includes saprophytic species, as well as plant pathogens, being widely distributed throughout tropical and subtropical areas of the world (Burgess 1981). Fusarium wilt, caused by the fungus Fusarium oxysporum f. sp. vasinfectum (Atk) Snyder \& Hansen, is one of the most important diseases on Malvaceae species in Brazil. The pathogen causes vascular wilt in okra and cotton (Cia and Salgado 1997). The first report of $F$. oxysporum f. sp. vasinfectum in Brazil occurred in 1935, infecting the cotton variety 'Texas' in Paraíba State (Silva et al. 2007b). The disease has been responsible for significant yield losses in many areas where this crop is grown (Silva et al. 2007a).

The management of Fusarium wilt in Malvaceae hosts is difficult, and the main control strategy has been preventing the introduction of the pathogen in new planting areas

\footnotetext{
${ }^{1}$ Universidade Federal Rural de Pernambuco (UFRPE), Departamento de Agronomia, A v. Dom Manuel de Medeuiros s/n, 52.171-900, Recife, PE, Brazil

2 Embrapa Hortaliças, CP 218, 70.359-970, Brasilia, DF, Brazil. *E-mail: ailton.reis@embrapa.br
} 
(Davis et al. 2006). Other disease management methods are crop rotation and seed treatment with fungicides (Davis et al. 2006). In the literature, there is an overall lack of information about the worldwide employment of okra cultivars with genetic resistance to Fusarium wilt. In Brazil, about $80 \%$ of okra fields are currently occupied by the open-pollinated cultivar 'Santa Cruz-47' (Associação Brasileira do Comércio de Sementes e Mudas - http:// www.abcsem.com.br/dadosdosegmento.php). However, no information is available about the resistance levels of this variety to this pathogen. Furthermore, new cultivars are continually being released by okra breeding programs. Therefore, it would be of practical interest to evaluate and characterize the reaction of okra germplasm accessions to diseases of potential economic threat, such as Fusarium wilt. In this context, the current work was conducted to evaluate (under greenhouse conditions) an okra germplasm collection, aiming to identify sources of resistance to Brazilian isolates of $F$. oxysporum f. sp. vasinfectum, and to study the resistance to two pathogen isolates in promising okra accessions.

\section{MATERIALS AND METHODS}

\section{Evaluation of resistance of okra accessions to Fusarium oxysporum f. sp. vasinfectum isolates}

Fifty-three okra accessions were screened in a preliminary assay (carried out in March 2010 in BrasíliaDF, Brazil) aiming to identify sources of resistance to F. oxysporum f. sp. vasinfectum. Fifty accessions used in this test were originated from the germplasm bank of Embrapa-Cenargen and three (viz. 'CNPH-001'; 'CNPH055', and 'CNPH-056') were obtained from the germplasm bank of Embrapa Hortaliças (Embrapa Vegetable Crops). In addition, the levels of resistance of 'Santa Cruz-47' cultivar (the leader commercial variety in Brazil) were also investigated. The $F$. oxysporum f. sp. vasinfectum isolate 'Fus-194' (from the mycological collection of the CNPH) was used in this assay. 'Fus-194' was originally collected on okra plants cultivated in Maranhão State (Northwest Brazil). Before sowing, seeds were immersed in ethanol $\left(92.8^{\circ} \mathrm{GL}\right)$ for 60 minutes in order to break their dormancy. After this period, the seeds were washed in running water and the excess of moisture was removed with paper towels. The plantlets were cultivated in styrofoam trays with 128 cells filled with Plantmax ${ }^{\circledR}$ substrate, placing one seed in each cell, with a total of 60 seeds per accession. These trays were kept under greenhouse conditions for 21 days after sowing.

\section{Inoculum preparation and inoculation procedures}

This step started by recovering the fungal isolates, which were preserved in sterile water (Castellani 1939), and cultivating them on Petri dishes with potato-dextroseagar medium (PDA) (Menezes and Silva-Hanlin 1997). After seven days of incubation in a B.O.D incubator, three discs of the culture medium (5 $\mathrm{mm}$ diameter) containing conidia were removed from the plates and transferred to Erlenmeyer flasks containing $150 \mathrm{~mL}$ of potato-dextrose (PD) liquid medium. The fungus was incubated for seven days, under laboratory conditions $\left(20\right.$ to $28^{\circ} \mathrm{C}$ ), with continuous mechanical shaking. The conidial suspension was prepared under laboratory conditions seven days after the transfer to the PD medium. The suspension, containing a high concentration of conidia, was homogenized by manual shaking and then filtered through sterile gauze. Conidia concentration was estimated in a Neubauer's chamber and then adjusted to $10^{6}$ conidia $\mathrm{mL}^{-1}$. For inoculation, the plantlets (with two pairs of fully open leaves) were removed from the trays, and the substrate adhered to the roots was washed using sterile water. After that, the root tips (at approximately 5 $\mathrm{cm}$ down from the stalk) were cut with sterile scissors and then immersed into the conidial suspension for two minutes. After this time, the inoculated plantlets were transplanted into plastic pots containing $2 \mathrm{~kg}$ of sterile substrate (mix of $100 \mathrm{~L}$ of soil; $200 \mathrm{~g}$ of NPK fertilizer; $100 \mathrm{~g}$ of lime; $40 \mathrm{~g}$ of ammonium sulfate and $20 \mathrm{~L}$ of burnt rice husks). After transplanting, $5 \mathrm{~mL}$ of the conidial suspension was also placed in the soil around the stalks. The experimental design was completely randomized, with 54 treatments and three replications (one pot with four plants each). A pot with mock-inoculated control plants received the same treatment of root washing and cutting; however they were only immersed in sterile water.

\section{Evaluation}

The pots were kept in a greenhouse until clear symptoms were expressed. The evaluation was carried out nine days after inoculation, when external (yellowing, wilt and leaf fall) and internal symptoms (darkening of the veins) appeared in a sub-group of highly susceptible accessions. The internal symptoms were observed after cutting the plant stalks longitudinally, with the help of a razor blade. An ordinal disease severity scale, adapted from Reis et al. (2004), was used to evaluate the plant responses. The grades of this scale ranged from 0 to 4 , where: $0=$ plants with no symptoms; 1 = plants with no symptoms of wilt or yellowing, but with darkened vascular bundles; 2 = plants with intensely darkened vascular bundles and with incipient 
Search for sources of resistance to Fusarium wilt (Fusarium oxysporum f. sp. vasinfectum) in okra germplasm

wilt or yellowed leaves; 3 = plants with severe wilt, associated with yellowing and premature leaf drop; $4=$ dead plants. From the grades, a disease index (DI) was calculated essentially as described by McKinney (1923): DI (\%) = $100 . \Sigma[(f . v) /(n . x)]$, where DI = disease index; $f=$ number of plants with the same grade; $\mathrm{v}=$ observed grade; $\mathrm{n}=$ total number of plants evaluated and $\mathrm{x}=$ maximum grade on the scale. These DI data were grouped into classes according to the reaction to the pathogen observed in each accession: $0 \%=$ similar to an immune-like response (SI); $0.01-25 \%$ $=$ high level of resistance (HR); $25-50 \%=$ intermediate resistance (IR); 50-75\% = intermediate susceptibility (IS); and $75-100 \%=$ high level of susceptibility (HS) (Reis et al. 2004). Comparative analysis was carried out using DI data by Scott-Knott test $(\mathrm{p} \leq 0.05)$ with SISVAR software.

\section{Evaluation of the disease resistance response to two isolates of $F$. oxysporum f. sp. vasinfectum in contrasting okra accessions}

Thirty okra accessions displaying HR and IR, and two HS accessions were selected after the preliminary assay. These accessions were re-evaluated for the stability of their reaction to two FOV isolates ('Fus-194' and 'Fus201 ') in two distinct environmental conditions (in the dry and moderate temperature season in August 2010 and in the wet and warm season in October 2010). The isolate 'Fus-201' was obtained from okra plants cultivated in Pernambuco State, Brazil. The production of plantlets, preparation of the inoculum, inoculation, and evaluation were all performed following the same methodology described in the previous assay. The experimental design (in both assays) was completely randomized, in a factorial arrangement of 32 (okra accessions) by two (pathogen isolates), with three replications. Each replication was composed by a pot with four plants. The evaluation took place 12 days after inoculation, and the severity data were used to calculate the DI values. The data were submitted to ANOVA, and the means were compared by the ScottKnott test ( $p \leq 0.05)$. The significance estimation of the contrasts among the two inoculation seasons $x$ isolate and inoculation seasons $x$ okra accessions were carried out ( $\mathrm{p}$ $\leq 0.05)$ with SAS software.

\section{RESULTS AND DISCUSSION}

In the preliminary germplasm evaluation (carried out in $\mathrm{March} / 2010$ ), the average air temperature was $22.7^{\circ} \mathrm{C}$. Twenty-one okra accessions, out of the 54 evaluated, displayed a susceptible reaction to the pathogen (reaction classes IS and HS) (Table 1). Five of these accessions were considered highly susceptible (DI value ranging from 77.08
Table 1. Evaluation of the reaction of okra (Abelmoschus esculentum L.) accessions to Fusarium oxysporum f. sp. vasinfectum (isolate 'Fus-194')

\begin{tabular}{llllll}
\hline Accession & DI (\%) & Class $^{2}$ & Accession & DI (\%) & Class \\
\hline BR-1970 & 22.92 A & AR & BR-1490 & 45.83 A & IR \\
Santa Cruz-47 & 25.00 A & AR & BR-3034 & 47.92 A & IR \\
BR-2534 & 27.08 A & IR & BR-2186 & 47.92 A & IR \\
BR-1198 & 27.08 A & IR & BR-1201 & 47.92 A & IR \\
BR-2917 & 29.17 A & IR & BR-2194 & 47.92 A & IR \\
BR-1716 & 29.17 A & IR & BR-2488 & 49.31 A & IR \\
BR-2178 & 31.25 A & IR & BR-540 & 54.17 B & IS \\
BR-1635 & 31.25 A & IR & BR-2232 & 56.25 B & IS \\
BR-1422 & 31.25 A & IR & BR-1597 & 56.25 B & IS \\
BR-1325 & 31.25 A & IR & BR-2241 & 56.25 B & IS \\
BR-2321 & 33.33 A & IR & BR-2259 & 58.33 B & IS \\
BR-2542 & 33.33 A & IR & BR-2763 & 60.42 B & IS \\
CNPH-001 & 33.33 A & IR & BR-2267 & 60.42 B & IS \\
BR-2399 & 34.72 A & IR & BR-1678 & 60.42 B & IS \\
BR-0825 & 37.50 A & IR & BR-2330 & 62.50 B & IS \\
BR-1121 & 37.50 A & IR & BR-1538 & 64.58 B & IS \\
BR-1872 & 39.58 A & IR & BR-1783 & 64.58 B & IS \\
BR-0167 & 39.58 A & IR & BR-1601 & 66.67 B & IS \\
BR-1392 & 39.58 A & IR & CNPH-055 & 68.75 B & IS \\
BR-2429 & 39.58 A & IR & BR-2801 & 70.83 B & IS \\
CNPH-056 & 41.67 A & IR & BR-2101 & 70.83 B & IS \\
BR-1686 & 41.67 A & IR & BR-1171 & 70.83 B & IS \\
BR-2291 & 43.75 A & IR & BR-0795 & 77.08 B & AS \\
BR-2372 & 43.75 A & IR & BR-2453 & 77.08 B & AS \\
BR-2224 & 45.83 A & IR & BR-1791 & 79.17 B & AS \\
BR-2402 & 45.83 A & IR & BR-1708 & 83.33 B & AS \\
BR-1449 & 45.83 A & IR & BR-1996 & 85.42 B & AS \\
\hline
\end{tabular}

${ }^{1}$ Disease indices (DI) followed by the same upper-case letter (in the column) do not differ statistically by Scott-Knott test $(\mathrm{p} \leq 0.05) .{ }^{2}$ Classes of reaction to the disease: $0.00 \%=$ similar to immune $(\mathrm{SI}) ; 0.01-25.00 \%=$ high resistance $(\mathrm{HR}) ; 25.01-50.00 \%$ $=$ intermediate resistance (IR); $50.01-75.00 \%=$ intermediate susceptibility (IS); $75.01-100.00 \%=$ high susceptibility (HS), adapted from (Reis et al. 2004).

to $85.42 \%$ ). This result confirmed the high aggressiveness of 'Fus-194' isolate to okra. The levels of aggressiveness reported here for 'Fus-194' were similar to that reported by Drame (2004) after inoculation of a collection of okra cultivars with five African isolates of $F$. oxysporum f. sp. vasinfectum. Thirty-three accessions displayed intermediate to high levels of resistance, despite the high aggressiveness of 'Fus-194' isolate (Table 1). In this preliminary assay no accession presented an immune-like reaction to Fusarium wilt. However, the accessions 'BR-1970' and 'Santa Cruz-47' were considered highly resistant to this pathogen (Table 1). 
The lack of a specific methodology for evaluating the reaction of okra accessions to FOV led to the adaptation of a screening system previously employed to evaluate tomato germplasm for resistance to Fusarium wilt (Reis et al. 2004). The results obtained here indicated that this methodology can also be suitable for evaluation of okra accessions for resistance to FOV. Plants classified as intermediately and highly resistant were significantly different (Table 1) from plants which were considered intermediately and highly susceptible. The phenotypic classes of resistance displayed a good fit with the groupings of accessions obtained using the Scott-Knott test.

In the dry/colder season (August/2010) assay, three of the 32 evaluated accessions were classified as highly resistant, and nine as intermediately resistant to 'Fus-194' isolate. Fourteen accessions were classified as intermediately, and six as highly susceptible (Figure 1). Only one accession was classified as highly resistant to 'Fus-201' isolate in this assay; eight accessions were allocated to the intermediately resistant group; 12 accessions, to intermediately susceptible; and 11, to the highly susceptible group (Figure 1). Although $44 \%$ of accessions were found to have intermediate susceptibility to 'Fus-194', when the intermediately and highly susceptible accessions were added, the frequency of accessions displaying some level of susceptibility was $63 \%$ (Figure 1). The comparison of the two isolates indicated that 'Fus-201' is more aggressive than 'Fus-194'. The isolate 'Fus-201' induced intermediately and highly susceptible response in 23 accessions (Figure 1). In the dry season assay, it was once again possible to discriminate the accessions into the same reaction classes proposed earlier. However, the resistance classes did not perfectly fit with the grouping obtained with the Scott-Knott test (Table 2). In this case, the accessions clustered into two classes, where the first included the highly and intermediately resistant classes, and the second, the other two classes. However, in the case of 'Fus-201' isolate, a perfect correlation was not observed for some accessions. This result is probably explained by the high aggressiveness presented by this isolate. Another possibility is the effect of environmental factors on disease expression, which is a characteristic typically associated with polygenic (horizontal) resistance (Parlevliet and Zadocks 1977).

In the warm/wet season assay (October/2010), the same 32 okra accessions were re-evaluated as in the previous assay. Seventeen $(50 \%)$ accessions were classified into the intermediately resistant group and seven as highly resistant to the isolate 'Fus-194'. Eight accessions were classified as intermediately susceptible and only one behaved as highly susceptible (Figure 2). For 'Fus-201' isolate, nine accessions were classified as intermediately resistant and one as highly

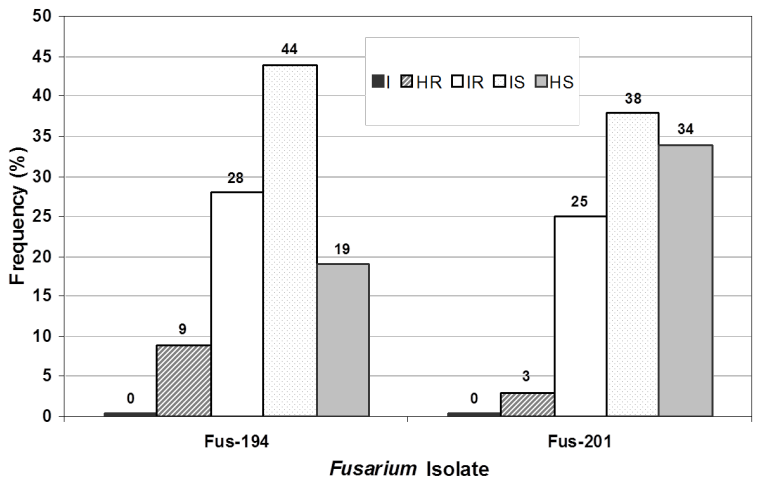

Figure 1. Frequency of each reaction class after evaluation under greenhouse conditions of $33 \mathrm{okra}$ accessions against two isolates of Fusarium oxysporum f. sp. vasinfectum ('Fus-194' and 'Fus-201'). The assays were conducted during the dry season (August, 2010). Reaction classes: (I) immune-type response; (HR) high resistance; (IR) intermediate resistance; (IS) intermediate susceptibility; and (HS) high susceptibility.

resistant. Nineteen accessions displayed an intermediate susceptible reaction, and three, a high susceptible reaction (Figure 2). In the warm/wet season experiment, the ScottKnott test was also able to discriminate the accessions into two classes of reaction for both isolates (Table 2). However, no correlation was observed among the reaction classes as shown by the statistical test and by the previously proposed pathogen reaction classification.

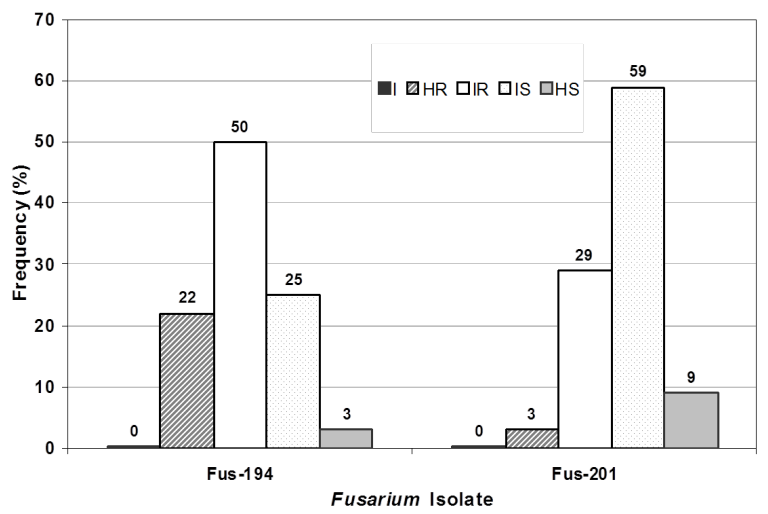

Figure 2. Frequency of each reaction class after evaluation under greenhouse conditions of $33 \mathrm{okra}$ accessions against two isolates of Fusarium oxysporum f. sp. vasinfectum ('Fus-194' and 'Fus-201'). The assays were conducted during the wet season (October 2010). Reaction classes: (SI) immune-type response; (HR) high resistance; (IR) intermediate resistance; (IS) intermediate susceptibility; and (HS) high susceptibility.

Analysis of the interactions among inoculation seasons $x$ isolates indicated that the patterns of interaction of 'Fus194' and 'Fus-201' isolates with okra accessions is affected by the inoculation/evaluation season. The overall level of symptom expression of both isolates was reduced during the assay conducted in the wet and warm season in October when compared with the dry/cold season assay (August), being 
Table 2. Resistance of okra accessions to two isolates of Fusarium oxysporum f. sp. vasinfectum in greenhouse assays conducted during the dry (August, 2010) and wet (October, 2010) seasons

\begin{tabular}{|c|c|c|c|c|c|c|c|c|}
\hline \multirow{3}{*}{$\begin{array}{l}\text { Acessions } \\
\text { BR-2429 }\end{array}$} & \multicolumn{4}{|c|}{ August 2010} & \multicolumn{4}{|c|}{ October 2010} \\
\hline & \multicolumn{2}{|c|}{ Isolate FUS-194 } & \multicolumn{2}{|c|}{ Isolate FUS-201 } & \multicolumn{2}{|c|}{ Isolate FUS-194 } & \multicolumn{2}{|c|}{ Isolate FUS-201 } \\
\hline & $16.67^{1}$ & $\mathrm{aA}$ & $75.00^{1}$ & $\mathrm{bB}$ & $47.92^{1}$ & $\mathrm{aB}$ & $58.33^{1}$ & $\mathrm{aB}$ \\
\hline BR-1635 & 20.83 & $\mathrm{aA}$ & 25.00 & $\mathrm{aA}$ & 31.25 & $\mathrm{aA}$ & 63.89 & $\mathrm{bB}$ \\
\hline BR-2372 & 27.08 & $\mathrm{aA}$ & 50.00 & $\mathrm{aA}$ & 56.25 & $\mathrm{aB}$ & 87.5 & $\mathrm{bB}$ \\
\hline S. Cruz-47 & 29.17 & $\mathrm{aA}$ & 47.92 & $\mathrm{aA}$ & 25.00 & $\mathrm{aA}$ & 25.00 & $\mathrm{aA}$ \\
\hline BR-1449 & 31.25 & $\mathrm{aA}$ & 37.50 & $\mathrm{aA}$ & 33.33 & $\mathrm{aA}$ & 43.75 & $\mathrm{aA}$ \\
\hline BR-2186 & 39.58 & $\mathrm{aA}$ & 56.25 & $\mathrm{aA}$ & 75.50 & $\mathrm{aB}$ & 68.06 & $\mathrm{aB}$ \\
\hline BR-2399 & 39.58 & $\mathrm{aA}$ & 35.42 & $\mathrm{aA}$ & 27.08 & $\mathrm{aA}$ & 43.75 & $\mathrm{aA}$ \\
\hline BR-2402 & 41.67 & $\mathrm{aA}$ & 62.50 & $\mathrm{aA}$ & 6.94 & $\mathrm{aA}$ & 52.08 & $\mathrm{bA}$ \\
\hline BR-1686 & 54.17 & $\mathrm{aB}$ & 50.00 & $\mathrm{aA}$ & 43.75 & $\mathrm{aB}$ & 54.17 & $\mathrm{aA}$ \\
\hline BR-1970 & 54.17 & $\mathrm{aB}$ & 70.83 & $\mathrm{aB}$ & 60.42 & $\mathrm{aB}$ & 35.42 & $\mathrm{aA}$ \\
\hline BR-1422 & 56.25 & $\mathrm{aB}$ & 79.17 & $\mathrm{aB}$ & 45.83 & $\mathrm{aB}$ & 62.50 & $\mathrm{aB}$ \\
\hline BR-0825 & 58.33 & $\mathrm{aB}$ & 75.00 & $\mathrm{aB}$ & 25.00 & $\mathrm{aA}$ & 47.22 & $\mathrm{aA}$ \\
\hline BR-2194 & 58.33 & $\mathrm{aB}$ & 50.00 & $\mathrm{aA}$ & 25.00 & $\mathrm{aA}$ & 33.33 & $\mathrm{aA}$ \\
\hline BR-1872 & 62.50 & $\mathrm{aB}$ & 41.67 & $\mathrm{aA}$ & 43.75 & $\mathrm{aB}$ & 77.78 & $\mathrm{bB}$ \\
\hline BR-1325 & 62.50 & $\mathrm{bB}$ & 29.17 & $\mathrm{aA}$ & 25.00 & $\mathrm{aA}$ & 66.67 & $\mathrm{bB}$ \\
\hline BR-1708 & 62.50 & $\mathrm{aB}$ & 87.50 & $\mathrm{aB}$ & 43.06 & $\mathrm{aB}$ & 62.50 & $\mathrm{aB}$ \\
\hline BR-2291 & 63.89 & $\mathrm{aB}$ & 79.17 & $\mathrm{aB}$ & 43.75 & $\mathrm{aB}$ & 66.67 & $\mathrm{aB}$ \\
\hline BR-2224 & 77.08 & $\mathrm{aB}$ & 64.58 & $\mathrm{aA}$ & 50.00 & $\mathrm{aB}$ & 64.58 & $\mathrm{aB}$ \\
\hline BR-2488 & 81.25 & $\mathrm{aB}$ & 85.42 & $\mathrm{aB}$ & 66.67 & $\mathrm{bB}$ & 31.25 & $\mathrm{aA}$ \\
\hline BR-1198 & 83.33 & $\mathrm{aB}$ & 72.92 & $\mathrm{aB}$ & 31.25 & $\mathrm{aA}$ & 52.78 & $\mathrm{aA}$ \\
\hline BR-1490 & 85.42 & $\mathrm{aB}$ & 81.25 & $\mathrm{aB}$ & 39.58 & $\mathrm{aA}$ & 54.17 & $\mathrm{aA}$ \\
\hline CNPH-056 & 89.58 & $\mathrm{aB}$ & 62.50 & $\mathrm{aA}$ & 62.50 & $\mathrm{aB}$ & 91.67 & $\mathrm{bB}$ \\
\hline BR-0167 & 97.22 & $\mathrm{aB}$ & 88.89 & $\mathrm{aB}$ & 56.94 & $\mathrm{aB}$ & 56.25 & $\mathrm{aB}$ \\
\hline
\end{tabular}

${ }^{1}$ Disease indices (DI) followed by the same lower-case letter in the row and same upper-case letter in the column do not differ statistically (Scott-Knott test at $\mathrm{p} \leq 0.05$ ).

'Fus-194' the most negatively affected isolate. This result is somewhat surprising since the warm season is supposed to be more conductive for the disease onset and progression. One possible explanation for this set of results is the fact that the genus Abelmoschus is not adapted to mild temperatures, whereas FOV's ability to cause disease is less affected by temperature fluctuations due to the natural phenotypic/genetic plasticity of this group of pathogens. In fact, it was noticed that the overall growth and development of the okra accessions was less vigorous during the dry/cold season assay.

The set of assays reported here reinforces the notion that there are differences in the level of aggressiveness of the fungal isolates. 'Fus-201' displayed greater levels of aggressiveness when compared to 'Fus-194' isolate (Figures 1 and 2). Comparing the two assays that were carried out in different 
environmental conditions, it could be observed that, in the August assay, the overall aggressiveness of 'Fus -194' and Fus-201' against the accessions under evaluation was more intense than in the assay carried out in October (Figures 1 and 2). Thirty-seven percent of the accessions inoculated with 'Fus-194', were resistant (HR + IR) in the August assay, whereas $72 \%$ of the accessions were considered resistant in October (Figures 1 and 2). When inoculated with 'Fus-201' isolate, the difference due to putative environmental influence was not so obvious. However, the impact of the evaluation season on the levels of resistance was observed when comparing the $28 \%$ of accessions classified as resistant in August, in contrast with $32 \%$ identified in October (Figures 1 and 2). This can be explained by the difference in temperature at the time of the assays, which is an important environmental effect when quantitative (horizontal) resistance is involved (Parlevliet and Zadocks 1977). From these two assays it was also seen that none of the evaluated accessions presented an immune-type reaction to the pathogen isolates. Thus, it was suggestive that these accessions might not have strong vertical resistance genes to these isolates. The phenotypic expression of this vertical resistance is usually associated with an immunity-like reaction (a typical qualitative effect), which might be specific to a particular variant of the pathogen (Parlevliet and Zadocks 1977).

During the second assay (August/2010), the average maximum temperature was $28{ }^{\circ} \mathrm{C}$ and the minimum, 11.7 ${ }^{\circ} \mathrm{C}$, with an overall average of $19.8^{\circ} \mathrm{C}$. In the October assay, the average maximum temperatures was $32.4{ }^{\circ} \mathrm{C}$ and the minimum was $17.7^{\circ} \mathrm{C}$, with an overall average of $25^{\circ} \mathrm{C}$. According to Filgueira (2003), okra is a plant species that does not tolerate low temperatures having an optimum temperature range located between 20 and $30^{\circ} \mathrm{C}$. Therefore, the higher aggressiveness presented by isolates in the August assay may be explained by the unfavorable temperature conditions for growth and development of okra accessions, among other factors, which may have increased its predisposition to disease.

In all assays, a clear-cut FOV isolate-specific response was observed in four accessions. The accessions 'BR-2429', 'BR-2534', and 'BR-3034' were classified as resistant to isolate 'Fus-194', but susceptible to 'Fus-201', whereas the accession 'BR-1325' was classified as susceptible to 'Fus194' and resistant to 'Fus-201'. The accessions 'BR-1635', 'BR-2372', 'BR-1449', 'BR-2186', 'BR-2399', 'BR-2402', 'BR-1996', 'BR-2917', and cultivar 'Santa Cruz-47' were resistant to both isolates (Table 2). This observation is in agreement with the conceptual basis of quantitative resistance, where variable levels of resistance are observed against different variants of the pathogen (Miranda et al. 2010), but it might also indicate that there is additional genetic variability for FOV resistance factors in this okra germplasm collection. In the October assay, nine accessions displayed no correlation of their response for two FOV isolates. The accessions 'BR-2402', 'BR-1121', 'BR-1716', 'BR-1325', 'BR-1635', 'BR-1872', 'BR-2372', and 'CNPH-056' were classified as resistant to isolate 'Fus-194' and susceptible to 'Fus-201', whereas accession 'BR-2488' was susceptible to 'Fus-194' and resistant to 'Fus-201' (Table 2). On the other hand, the accessions 'BR-2194', 'BR-825', 'BR-2399', 'BR-1198', 'BR-1449', 'BR-2534', 'BR-1490', and cultivar 'Santa Cruz47 ' were significantly resistant to the two isolates (Table 2). The accessions 'BR-2399', 'BR-1449', and 'Santa Cruz-47' were the only ones that displayed high levels of resistance to both isolates in all three assays. These results indicate that these three accessions might represent promising sources of stable and durable resistance to Fusarium wilt. Accessions 'BR-2399' and 'BR-1449' could be used in future breeding programs and also evaluated under field conditions to observe their agronomic characteristics and fruit quality traits.

In regarding to the cultivar 'Santa Cruz-47', the results confirm its resistance to distinct FOV isolates obtained in two important okra production areas of Brazil (Maranhão and Pernambuco States). 'Santa Cruz-47' has been reported as a source of resistance to verticillium wilt, caused by the fungus Verticillium dahliae (Filgueira 2003), and to begomovirus (Aranha et al. 2011). As far as it is known, this work is the first formal report of resistance to Fusarium wilt in this cultivar. This is valuable information for the breeding standpoint. 'Santa Cruz-47' is already a pyramid of distinct resistance genes to three of the most limiting okra diseases in the tropics. In addition, this variety has also superior agronomic and commercial fruit characteristics. The cultivar 'Santa Cruz-47' has been widely used for about four decades in Brazil (Sudo et al. 1974, Aranha et al. 2011) without either being replaced by more modern cultivars or found infected by verticillium wilt (Filgueira 2003) and okra mosaic disease caused by begomovirus species (Aranha et al. 2011). Therefore, the Brazilian cultivar 'Santa Cruz-47' represents one of the most interesting germplasm for genetic improvement targeting tropical areas. This source of multiple resistance factors (including resistance to Fusarium wilt), in combination with a favorable set of agronomic characteristics, might be one of the main factors explaining its broad adaptability, robustness and long-lasting commercial success in Brazil.

\section{ACKNOWLEDGMENTS}

The authors are grateful to CNPq (National Center for Scientific Research) for financial support and to Dr. Antonio Williams Moita for helping with statistic analysis. 


\section{Busca por fontes de resistência à murcha de fusário (Fusarium oxysporum f. sp. vasinfectum) em germoplasma de quiabo}

Resumo - Fusarium oxysporum f. sp. vasinfectum (FOV) é um dos patógenos mais destrutivos do quiabeiro (Abelmoschus esculentus) no Brasil. Cinquenta e quatro acessos de quiabeiro foram avaliados quanto à resistência a FOV em casa de vegetação. Inicialmente foi conduzida uma seleção com o isolado 'Fus-194'. Trinta e três acessos, que foram resistentes na seleção inicial, foram reavaliadas em dois ensaios adicionais (sob duas condições de ambiente), utilizando dois isolados de FOV. Destes, onze acessos foram classificadas como altamente ou medianamente resistentes ao isolado 'Fus-194' em agosto (estação seca e com temperatura moderada), enquanto que $28 \%$ dos acessos foram classificados como altamente ou medianamente resistentes ao isolado 'Fus-201'. No ensaio conduzido na estação úmida e quente, $72 \%$ dos acessos apresentaram reação de alta a média resistência a 'Fus-194', enquanto que $32 \%$ foram resistentes a 'Fus-201'. A cultivar 'Santa Cruz-47'e os acessos 'BR-2399'e 'BR-1449'foram as fontes de resistência mais promissoras.

Palavras-chave: Abelmoschus esculentus, caracterização de germoplasma, reistência genética, melhormento genético.

\section{REFERENCES}

Aranha AS, Albuquerque LC, Boiteux LS and Inoue-Nagata AK (2011) Detection and complete genome characterization of a begomovirus infecting okra (Abelmoschus esculentus) in Brazil. Tropical Plant Pathology 36: 14-20.

Burguess LW (1981) General ecology of the fusaria. In Nelson PE, Tousson TA and Cook RJ (eds.) Fusarium disease, biology and taxonomy. Pennsylvania University Press, University Park/London, p. 225-235.

Castellani A (1939) Viability of some pathogenic fungi in distilled water. Journal of Tropical Medicine and Hygiene 42: 225.

Cia E and Salgado CL (1997) Doenças do algodoeiro (Gossypium spp.). In Kimati H, Amorim L, Rezende JAM, Bergamin-Filho A and Camargo LEA (eds.) Manual de fitopatologia: doenças das plantas cultivadas. $4^{\text {th }}$ ed, v. 2, Agronômica Ceres, São Paulo, p 41-52.

Drame A (2004) Pathogenie comparée de quelques souches de Fusarium oxysporum f. sp. vasinfectum Atk. , agent de la fusariose du gombo (Abelmoschus esculentus L.) Au Senegal. Agronomie Africaine 16: $33-38$.

Davis RM, Colyer PD, Rothrock CS and Kochman JK (2006) Fusarium wilt of cotton: population diversity and implications for management. Plant Disease 90: 692-703.

Filgueira FAR (2003) Novo manual de olericultura: agrotecnologia moderna na produção e comercialização de hortaliças. $2^{\text {nd }} \mathrm{ed}$, UFV, Viçosa, 421p.

McKinney HH (1923) Influence of soil temperature and moisture on infection of wheat seedlings by Helminthosporium sativum. Journal of Agricultural Research 26: 195-218.

Menezes M and Silva-Hanlin DMW (1997) Guia prático para fungos fitopatogênicos. UFRPE, Imprensa Universitária, Recife, 106p.
Miranda BEC, Boiteux LS, Cruz EM and Reis A (2010) Fontes de resistência em acessos de Solanum (secção Lycopersicon) a Verticillium dahliae raças 1 e 2. Horticultura Brasileira 28: 458-465.

Oliveira AP, Alves AU, Dornelas CSM, Silva JA, Porto ML and Alves AU (2003) Rendimento de quiabo em função de doses de nitrogênio. Acta Scientiarum Agronomy 25: 265-268.

Parlevliet E and Zadoks JC (1977) The integrated concept of disease resistance: a new view including horizontal and vertical resistance in plants. Euphytica 26: 5-21.

Reis A, Giordano LB, Lopes CA and Boiteux LS (2004) Novel sources of multiple resistance to three races of Fusarium oxysporum f. sp. lycopersici in Lycopersicon germplasm. Crop Breeding and Applied Biotechnology 4: 495-502.

Silva EKC, Rodrigues AACR and Veras MS (2007a) Efeito de resíduos orgânicos na supressão de Fusarium oxysporum f. sp. vasinfectum. Revista Brasileira Agroecologia 2: 1255-1258.

Silva VAS, Juliatti FC and Juliatti FC (2007b) Estudo preliminar da variabilidade de Fusarium oxysporum f. sp. vasinfectum em Gossypium hirsutum. Bioscience Journal 23: 1-6.

Sudo S, Ribeiro RLD, Kimura O, Akiba F and Robbs CF (1974) Santa Cruz-47, nova variedade de quiabeiro (Hibiscus esculenta L.) com resistência a doenças prevalentes na Baixada Fluminense. Fitopatologia 9: 72-73.

Torres SB and Carvalho IMS (1998) Teste de envelhecimento acelerado em sementes de quiabo (Abelmoschus esculentus (L.) Moench). Revista Brasileira de Sementes 20: 209-211.

Veras MS and Silva AC (2007) Controle biológico como alternativa para a agricultura familiar no Maranhão: efeito supressor de fitopatógeno. Revista Brasileira de Agroecologia 2: 1457-1460. 
FM Aguiar et al. 